\title{
ACTUARIAL ACTIVITY IN GENERAL INSURANCE IN THE NORTHERN COUNTRIES OF EUROPE
}

\author{
L. Wilhelmsen, \\ Oslo
}

Read to ASTIN, Wednesday, I6th Oct. 1957

\section{Introduction - The demand for Actuaries in General Insurance}

Although actuaries have been connected with life insurance business for more than Ioo years, it is only more recently that actuarial activities in the non-life branches have taken place.

The problem of calculating level premiums for the steadily increasing risk in life insurance immediately calls for mathematical ability. The need for mathematically trained specialists is not so easily seen when the problem is to calculate premium rates for fire and casualty insurances. The premium rates in this field have to a great extent been fixed by persons with none or very little knowledge in mathematics and mathematical statistics. When the market conditions allow for considerable margins this arrangement works out very well. The statistical investigation needed later on for controlling the premium rates is not very complicated, and the premium rates can if necessary be changed on short notice. A mistake made in the premium stipulation, will generally not have a lasting effect. In life insurance on the other hand, the contracts often stretch over many years and a mistake in the premium stipulation cannot easily be corrected. These circumstances explain the reason why actuaries have been more often engaged in life insurance than in the fire and casualty branches.

But a closer study shows that from a mathematical point of view, the proper fixing of premium rates is often more complicated in the fire and casualty branches than in life. In the fire and casualty field a steady changing of market conditions seems to take place. The competition grows keener and keener, and the margins are cut down. Sooner or later we reach a point where it is of vital importance to know as exactly as possible where we stand. This 
means that we have to study the risk premium, the security loading and the expense loading separately, and to estimate these quantities with the highest efficiency.

Also in the reinsurance field there are many questions calling for knowledge of mathematics and mathematical statistics. Among these questions, the retention problem should especially be mentioned. In earlier days when margins on premium and commission rates were larger, it was of no great importance how the retention limits in the surplus treaties were fixed, if only they were low enough. But when the margins are low and the possibility of getting reciprocity of the same quality as the reinsurance given away is small, it grows more and more important to fix retention limits which are not too low. To do this, it is necessary to have a clear definition of the aim of reinsurance. This definition must be translated into a mathematical language, to be the starting point for theoretical investigations.

During recent years there has been a tendency towards an increased use of non-proportional reinsurance forms, such as excess of loss, stop loss etc. The calculation of premium for covers such as these also requires a certain amount of mathematical knowledge.

There are, as we have seen, problems of vital importance for the fire and casualty insurance branches which call for actuarial knowledge, and it can be expected that the number of actuaries working in this field will increase in years to come. Many of the problems with which these actuaries will deal are new problems for which no ready made solutions exist. But the problems are the same or very similar from one country to the other, and a good deal of work could therefore be saved by collaboration between actuaries from different countries. This is the way in which I have seen the background for the establishment of the Astin group of actuaries. The Astin collaboration group will make the results obtained by actuaries in one country available for actuaries in other countries. AsTin will also instil in their membership the desire for further research above and beyond the normal daily problems. Results of such studies and research will elevate our profession to a high scientific level. 


\section{The Education of Actuaries}

I am going to give you some information about the actuarial activity in general insurance in the northern countries of Europe, that means in Denmark, Finland, Norway and Sweden.

The education of actuaries is very similar in Denmark and Norway and the systems adopted in these two countries are different from the systems which are used in Finland and Sweden. In Denmark and Norway there is a special degree for actuaries at the universities. The actuarial students have to follow a course of study and to pass various examinations which are set up for them. In both these countries the education of actuaries consists of studies in pure mathematics, insurance mathematics and mathematical statistics, and in economics. The students very often have jobs in insurance companies during the time of their study, and therefore need considerable time in order to finish their studies. If a student were to use all of his available time in pursuit of these studies it has been estimated that he would require six years. In Sweden the education of actuaries also takes place at the university but there are no special degrees for the actuaries. The young students wishing to become actuaries can therefore to a certain extent choose between different courses. To be approved as chief actuaries in life insurance companies the students have in practice to pass an examination in mathematics and in insurance mathematics with mathematical statistics. In Finland the students study mathematics at the university, but there are no courses in insurance mathematics at the university. The persons who wish to be approved as chief actuaries in life insurance companies have to pass certain examinations to prove their ability in insurance mathematics and mathematical statistics. But these examinations do not take place at the university. The requirements which are necessary to pass these examinations are stipulated by the ministry of social affairs and the examination takes place under the supervision of this ministry.

As you will see from what I have said, the education of actuaries in all the northern countries in Europe aims at educating actuaries for the life insurance business. But as the actuaries have to go through rather extensive courses in mathematical statistics the same education is also well suited for actuaries in general insurance. 


\section{Actuarial activities within Non-life Insurance Companies}

Many companies in the Scandinavian countries and in Finland show an increasing interest in establishing a more scientific base for the premium calculations. These companies employ actuaries or other persons with knowledge in mathematical statistics. Especially in Sweden, a comparatively large number of actuaries are employed in general insurance companies, or in organisations closely connected with the companies. Many of these actuaries are busily engaged in research work, and our profession in Sweden stands on a very high scientific level. This is also proved by the many papers delivered by Swedish authors on Subject IV A at this congress.

The tariff organisations for automobile insurance employ actuaries in all four countries, and this is also the case with some of the tariff organisations for the other branches.

The collection and preparation of joint statistics from material from tariff companies, and other groups of companies, are supervised by actuaries in all four countries.

4. Collaboration between Actuaries employed in General Insurance

Different kinds of collaboration exist between actuaries employed in general insurance in the northern countries of Europe. The most important background for the collaboration is perhaps the personal contact that exists independent of the national borders. These personal contacts always make it easy for an actuary to collect information which he wants concerning conditions in other companies, in his own country, and in other Scandinavian countries. Through these contacts personal friendships between actuaries from different countries have grown, and as you know, such close relationships always make it easier to exchange views and to discuss problems of joint interest.

There also exist two organisations aiming at a collaboration between actuaries in the fire and casualty branches, and these two organisations are called the N.T.A. and the C.N.Ö.B.

The N.T.A. is a collaboration group of actuaries engaged with tariff companies and tariff organisations in our countries.

The main activity of this group consists of meetings where problems of joint interest are discussed. These meetings always 
take place outside the cities and last for two or three days. The number of members attending these meetings has been between fifteen and twenty. Up to the present three such meetings have taken place and their success was due to the fact that the small number attending permitted everyone to take an active part in the discussions.

Another organisation aiming at joint actuarial activity in the northern countries in Europe, is the C.N.Ö.B. which means the northern central for fire insurance statistics from mutual companies. The activity of this organisation is managed by a board consisting of four members, one from each country. The aim of the organisation is to collect statistical material from all of the four countries and to work out joint statistics. The organisation regularly each year prints a paper giving a general view of the fire insurance conditions during the last year in each of the four countries. In addition the publication contains statistics about all of the large fires that have taken place in the northern countries during the last year. In addition to this regular publication the organisation from time to time also prints reports on special investigations which have been undertaken.

\section{Actuarial problems from General Insurance in the Scandinavian Actuarial Journal and in the Actuarial Societies}

In all the four countries, papers dealing with actuarial problems from general insurance are from time to time presented in the actuarial societies. The Scandinavian actuarial journal also prints papers dealing with such problems.

The problems which actuaries in our countries have treated in the last years are distributed over a wide range of topics. I shall mention some of these topics, but it is not possible to mention the names of the actuaries who dealt with each topic and the conclusions reached by all of them.

First I will mention the collective theory of risk which is of Scandinavian origin and to the development of which many actuaries from our countries have contributed. As is very often the case with theories from the economic field the collective theory of risk was originally based on suppositions which do not always occur in real life, in order to avoid some of the difficulties which would 
otherwise arise. The later work has to a great extent been directed towards the treatment of the theory in cases where suppositions made more closely reproduce real life. This has been a wide field for further research and the conclusions reached have certainly made the application of the collective theory of risk easier. At this stage it can certainly be said that the theory is a tool of great practical importance for fixing the companies' retention limits.

A few of the more important questions dealt with in connection with the premiums calculation are as follows:-

The risk premium in fire insurance as a function of the dimensions of the house.

The risk premium in traffic insurance as a product of different factors, each of which is dependent on a smaller number of moments than is the risk premium.

How to judge the largest claims statistically, and how to draw conclusions from such rare events by the stipulation of premiums.

The use of comprehensive policies and the premium stipulation for such policies.

The premium for fire insurance as a function of the distance to the neighbouring risk.

The premium stipulation for crop insurance.

6. Astin

The establishment of the Astin group of actuaries and the organisation of this group as a section of the Permanent Committee of the International Congress of Actuaries, has been met with much enthusiasm in the northern countries in Europe. We really hope that it will be of great value for our profession, but very much depends upon the activity of the members and their willingness to publish papers and to take an active part in the discussions.

Further, as a means of contact between actuaries from different countries Astin can be very useful. It is an idea worth considering that actuaries who are interested in special problems should register this with Astin and that Astin should put them in contact with colleagues interested in the same kind of problems. This would save work, create useful contacts and establish new friendships as well. 